\title{
Kemik İliği Kültür Sonucu İle Tanı Alan Bir Enfektif Endokardit Vakası
}

\author{
An Infective Endocarditis Case Diagnosed Via Bone Marrow Culture
}

\section{Elif M. Öztürk', Gülden Yılmaz¹, Derya Koyun², M. Cahit Sarıcaoğlu³ , K. Osman Memikoğlu}

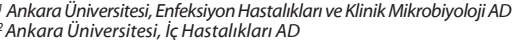

Ankara Üniversitesi, Kalp ve Damar Cerrahisi AD

Geliș tarihi : 24.08.2014 • Kabul tarihi: 19.12.2014

İletișim

Dr. Elif Mukime ÖZTÜRK

Tel: 0 (312) 5082937

E-posta: elifmozturk@gmail.com

Ankara Üniversitesi Tıp Fakültesi íbni Sina Araștırma ve

Uygulama Hastanesi Enfeksiyon Hastalıkları ve Klinik

Mikrobiyoloji Anabilim Dalı M 01 Blok Samanpazarı/ANKARA

Giriș: Enfektif endokardit (EE) tanısında vakaların klinik farklılıkları nedeni ile zorluklar yașanmaktadır. Burada kan kültürleri negatif olmasına rağmen kemik iliği aspirasyon kültüründe Streptococcus oralis üremesi sonucunda tanı alan bir EE olgusu sunulmuștur.

Olgu: Bilinen bir ek hastalığı olmayan kırk dört yașında erkek hasta ateș ve halsizlik șikayeti ile hastaneye bașvurdu. Enfeksiyon odağı saptanamayan hasta, takibi süresince ateșsiz seyretmiș olup ateșsiz dönemde alınan kan kültürlerinde herhangi bir üreme saptanmadı. Ateș etiyolojisine yönelik yapılan transtorasik ekokardiyografide (TTE) ve torakal-abdominal-pelvik bilgisayarlı tomografisinde herhangi bir enfeksiyon odağına rastlanmadı. Bilateral inguinal ve aksiller lenfadenopatileri olan hastanın yapılan aksiller lenf nodu biyopsisi sonucu malignite ile uyumlu olmadığı görüldü. Takibi süresince ateși olmayan hastanın; anemisi, lökositozu ve lenfadenopatisi olması nedeni ile tanıya yönelik yapılan kemik iliği biyopsisi sonucunda enfeksiyona sekonder myeloid seride artıș saptandı. Kemik iliği aspirasyon materyali kültüründe Streptococcus oralis üremesi oldu. EE açısından tekrarlanan TTE'de mitral kapak üzerinde hareketli yapılar, dördüncü derece mitral yetmezlik izlendi ve transözefageal ekokardiyografide (TEE) bu yapıların vejetasyon olduğu gösterildi. Hastanın tedavisi intravenöz sulbaktam ampisilin ve gentamisin olarak düzenlendi. Hastaya medikal tedavi altında mitral kapak replasmanı yapıldı. Kontrol ekokardiyografilerinde herhangi bir patolojik bulguya rastlanmayan hastanın tedavi süresi tamamlanarak kesildi. Takiplerine devam edilen hastanın izleminde herhangi bir sorun yașanmadı.

Sonuç: EE vakalarının klinik farklılıkları tanıyı güçleștirmektedir. Ateșsiz seyreden, kan kültürleri negatif olan ve ilk TTE'de vejetasyon görülmeyen bu vakada olduğu gibi ateș odağı araștırıırken EE klinik farklılıkları nedeni ile etiyolojide akılda bulundurulmalıdır.

Anahtar Sözcükler: Enfektif Endokardit, Kemik iliği Kültürü, Streptococcus Oralis

Introduction: There is a common difficuly in the diagnosis of infective endocarditis originating from the differences in the clinical presentations of these cases. Here, a case diagnosed with infective endocarditis as a result of the growth of Streptococcus oralis in the culture of bone marrow aspiration has been presented.

Case: A 44-year-old male patient without an additional known disease was admitted to the hospital with the complaints of fever and fatigue. During the patient's fever etiology, there were observed sources of infection neither in the transthoracic echocardiography (TTE) nor in the thoracic-abdominal-pelvic computer tomography data. The results of the patients with bilateral inguinal and axillary lymphadenopathy who underwent axillary lymph node biopsy were not consistent with malignancy. During the follow-up of the patient without fever, due to the fact that the patient had anemia, leukocytosis and lymphadenopathy, it was determined by the diagnostic bone marrow biopsy that there was an increase in the proportion of myeloid series which may be a secondary to infection. A growth of Streptococcus oralis was observed by the tests of the bone marrow aspiration growth material culture. A fourth degree mitral regurgitation was observed on the repeated TTE flail structures of the mitral valve in terms of infective endocarditis, and these structures were shown as vegetation in the transesophageal echocardiography (TEE). The treatment of the patient was determined as intravenous sulbactam ampicillin and gentamicin. A medical treatment with mitral valve replacement was performed on the patient. The patient without pathological findings during the control echocardiography. During the monitoring period, the patient did not face any problems.

Conclusion: The different presentations of the infective endocarditis cases make it difficult to establish an accurate diagnosis. As in this case, the patient with no fever, with negative blood cultures, and with no vegetation in the first TTE, different clinical presentations should be considered in the etiology during the investigation of the reason for fever.

Key Words: Infective Endocarditis, Bone Marrow Culture, Streptococcus Oralis

Oral streptokoklar gram pozitif, katalaz negatif heterojen mikroorganizmalar grubu olup; oral mukoza, gastrointestinal ve genitoüriner sistemde kolonize olabilirler. Önceleri 'dekstran-pozitif mitior' olarak tanımlanan Streptococcus oralis de oral streptokoklar grubunda yer almaktadır (1). Genellikle immünokompetan hasta grubunda düşük patojeniteli olup, belli hasta gruplarında endokardit, intraabdominal enfeksiyon ve şok gibi invazif hastalıklara neden olabilir (2). 
Enfektif endokardit (EE) tanısının konulmasında vakaların klinik farklılıkları nedeni ile zorluklar yaşanmaktadır (3). Burada kan kültürlerinde üreme olmamasina rağmen kemik iliği kültür sonucunda S. oralis üremesi sonrasinda tanı alan bir EE vakası sunulmuştur.

\section{OLGU}

İki aydır devam eden ateş ve halsizlik şikayeti olan kırk dört yaşında erkek hasta ateş etiyolojisi araştırılmak üzere servise yatırıldı. Hasta iki ay önce benzer şikâyetlerle diş merkeze başvurmuş, üst solunum yolu enfeksiyonu tanısı ile oral amoksisilin klavulonik asit tedavisi almıştı. Hastanın son bir aydır aralıklı olarak devam eden ve odağ1 saptanamayan ateşi mevcuttu. Bilinen bir ek hastalığ olmayan hastanın fizik muayenesinde; vücut sıcaklığ1 $37,2^{\circ} \mathrm{C}$, kan basinc1 110/75 mm/Hg, nabiz 85/dk olup bilateral inguinal ve aksillar bölgede en büyüğü yaklaşık bir santimetre çapında olan multiple ağrisız lenfadenopatiler dışında herhangi bir patolojik bulgu saptanmadi.

Laboratuvar tetkiklerinde; eritrosit sedimentasyon hiz1 (ESR) $61 \mathrm{~mm} / \mathrm{sa}$, beyaz küre 12,200x10/L (\%77,3 nötrofil), hemoglobin 12,3 gr/dl, CReaktif Peptid (CRP) $121 \mathrm{mg} / \mathrm{L}$ olarak saptanmış olup böbrek ve karaciğer fonksiyon testlerinde herhangi bir patolojik değere rastlanmadi. Ateş ve lenfadenopati etiyolojisine yönelik yapilan tetkiklerinde; Brusella Rose Bengal, Wright aglütinasyon, Sitomegalovirüs (CMV) IgM, Ebstein-Barr Virüs (EBV) IgM, Toksoplazma IgM negatif saptandi. Klinikteki takibinde ateşi olmayan hastanın EE açısından ateşsiz dönemde alınan 3 set kan kültürlerinde herhangi bir üreme olmadı. Çekilen transtorasik ekokardiyografide (TTE) vejetasyon lehine patolojik bir görüntüye rastlanmadı. Çekilen abdominal bilgisayarlı tomografide (BT) de hiyatal herni, her iki akciğerde çoğu plevraya yakın yerleşimli birkaç adet milimetrik (mm) nodül, sol böbrek orta kesim lateralde yumuşak doku dansitesinde lezyon (hemorajik kist), sol kaliks taşları, hepatomegali ve splenomegali saptandi. İnguinal ve aksiller bölgedeki lenfadenopatilere yönelik yapilan ultrasonografik görüntülemede (USG) bilateral inguinal ve aksiller reaktif görünümlü benign lenf nodları saptand. Yapılan aksiller lenf nodu eksizyonel biyopsi sonucu; malignite yönünde bulgu izlenmeyen, lipomatozis gösteren lenf nodülü olarak sonuçlandi. Anemi, lökositoz ve lenfadenopatisi olması nedeni ile tanıya yönelik yatışının 15 . gününde yapılan kemik iliği biyopsi yaymaları 'myeloid seri aktif ve maturasyonu normal, $\% 5$ in altinda blast oran1, enfeksiyone sekonder olabilecek "myeloid seride oran artış1 ve eritroid seride baskilanma" olarak raporland1. BACTEC Plus Aerobic/F besiyeri içeren kültür flakonuna inoküle edilen kemik iliği aspirasyon materyalinde Streptococcus spp. üremesi oldu. BD Phoenix otomatize mikrobiyoloji sistemi (Becton Dickinson, ABD) ile yapilan tiplendirme sonucu Streptococcus oralis (Penisilin için "Minimum inhibitör konsatrasyon" (Mİ) değeri $<0,125 \mathrm{mg} / \mathrm{L})$ olarak geldi. EE açısından 7 gün sonra tekrarlanan TTE'de mitral ön kapak ucunda hareketli yapılar ile dördüncü derecede mitral yetmezlik izlendi ve TEE'de bu yapilarin 2x1 cm boyutlarında vejetasyon olduğu görüldü. Hastanın oral hijyeni iyi olup, yakıı zamanda diş çekimi, geçirilmiş kalp kapak cerrahisi ya da intravenöz ilaç kullanım hikayesi gibi EE açısından herhangi bir risk faktörü bulunmamaktaydı. Hastanın tedavisi intravenöz sulbaktam ampisilin (4x3 gr/gün) ve gentamisin (1x1 mg/kg/gün) olarak düzenlendi. Tekrarlanan abdominal USG'de dalakta hipodens alanlar (infarkt?) saptand1. Tedavinin altıncı gününde hastaya kalp damar cerrahisi bölümünce antibiyotik tedavisi altında mitral kapak replasmanı yapıldı. Çekilen kontrol TTE'de vejetasyon lehine herhangi bir patolojik bulguya rastlanmayan hastanin sulbaktam ampisilin ve gentamisin tedavisi iki haftaya tamamlanarak kesildi. Hastanın tedavi sonu yapilan kan tetkiklerinde beyaz küre 8.300 (x10/L), CRP 3.3 (mg/L) ve sedimentasyonun 16'e ( $\mathrm{mm} / \mathrm{sa})$ gerilemiş olduğu görüldü. Takiplerine devam edilen hastanın izleminde herhangi bir sorun yaşanmadi.

\section{TARTIȘMA}

EE; çoğunlukla bakterilerle gelişen, kalp kapaklarının, konjenital kardiyovasküler lezyonların, prostetik kapak veya diğer prostetik materyallerin tutulumu ile seyreden bir hastaliktır (4). Normal kapak endoteli bakteri kolonizasyonuna dirençlidir. Endotelin mekanik olarak zarar görmesi; ekstraselüler matriks proteinlerinin açığa çıkıp doku faktörünün üretimine, fibrin ile trombositlerin birikmesine ve dolaşan mikroorganizmaların hasarlı endotel yüzeyine yapışmasına neden olmaktadir. Bakteriyeminin EE patofizyolojisindeki rolü; kateter ilişkili bakteriyel olmayan trombotik EE'li deney hayvanlarında gösterilmiştir. Bakteriyeminin miktarı ve patojenin hasarlı kalp kapağına yapışma gücünün önemli faktörler olduğu gösterilmiştir. Bakteriyeminin tek sebebi invazif prosedürler olmayıp çiğneme ve diş firçalama sirasinda da olabilmektedir. Bu şekildeki spontan bakteriyemilerin düşük dereceli ve kısa süreli olmasına rağmen, yüksek insidansa sahip olması; çoğu EE vakasının invazif prosedürlerden bağımsız gelişmesini açıklamaktadır (5). Diş çekimi, intravenöz ilaç kullanımı ya da herhangi bir cerrahi girişim öyküsü bulunmayan bu vakada EE gelişimi çiğneme ve diş firçalama sırasında oluşan geçici bakteriyemi ile ilişkili olabilir.

Karakteristik lezyon olan vejetasyon; trombosit, fibrin, mikroorganizma ve inflamatuar hücrelerden olușmaktadır (6). EE vakalarınin \%80' inden 
stafilokoklar ve streptokoklar sorumludur. Prostetik kapağ1 olan, düzeltilmemiş siyanotik konjenital kalp hastalığı ya da geçirilmiş EE hikayesi olan kişilerde EE görülme sıklığ1 daha fazla olmasina rağmen vakaların \%50'sinde bilinen bir kapak hastalığ1 hikayesi olmadığ görülmüştür (7). EE; tanı ve tedavi prosedürlerinde önemli gelişmeler olmasina rağmen, hala prognozu kötü seyirli ve mortalitesi yüksek bir hastalıktır. Başlangıç klinik prezentasyonlarının farklılığı, altta yatan kardiyak hastalığın varlığ1, etken mikroorganizma, komplikasyonun olup olmaması gibi faktörlere bağlı olarak farklı formlarda EE vakaları görülmektedir (5). Bu nedenle $\mathrm{EE}$ tanısının konulmasında güçlükler yaşanmaktadır (3).

EE klinik belirti ve bulguları oldukça değişkendir. Hastaların \%90’1 ateş ile başvurmaktadır (5). Ancak kongestif kalp yetmezliği, ileri yaş, üremi, karaciğer ve böbrek fonksiyon bozukluğu, daha düşük virülanslı mikroorganizmaların etken olması, önceden ya da başvuru anında antibiyotik kullaniyor olma durumunda vakaların \%5-10' unda ateş görülmeyebilir (4,6). Elbey ve arkadaşları tarafindan yapılan bir çalışmada ateş dışında en sık görülen semptomlar arasinda halsizlik, nefes darliğ1 ve gastrointestinal semptomların yer aldığı gösterilmişir (8). Bizim vakamı takibi süresince ateşsiz seyretmiş olup başvuru öncesinde antibiyotik kullanım hikayesinin olması ateşin baskılanmasına neden olmuş olabilir. Kardiyak üfürüm; EE'in en s1k bulgularından biri olup sağ kalp endokarditlerinin başlangıç evrelerinde görülemeyebilir. Endokardit vakalarının sadece \%40'ında yeni gelişimli ya da değişim gösteren üfürüm saptandığ1 gösterilmiştir (9). Halsizlik dişında ek bir şikayeti olmayan vakanın ekokardiyografide belirlenen dördüncü derece mitral yetmezliğe rağmen belirgin bir kardiyak kökenli semptom ve bulgusunun olmayışı oldukça şaşırtıcıdır.

Enfektif endokarditen genellikle ateş, yeni gelişimli ya da değişim gösteren üfürümü olan hastalarda şüphelenilmektedir.

Ekokardiyografide vejetasyon varlığ1 ve pozitif kan kültürleri ile de tanı konulmaktadır (9). EE vakalarının \%2,5-31'inde kan kültüründe üreme olmamaktadır. Farklı çalışmalarda kan kültürü negatifliğinin \%35 oranına kadar ulaştığ1 görülmüştür (8). Kan kültürünün negatif olmasinın nedenleri arasinda antibiyotik kullanım hikayesi, subakut sağ kalp endokarditi, mural endokardit, zor üreyen ya da zorunlu hücre içi olan mikroorganizmaların etken olması sayılmaktadır. En s1k neden olarak ise antibiyotik kullanım hikayesi belirtilmektedir (5). Bir New York serisinde önceden antibiyotik kullanımının streptokokkal endokarditlerde pozitif kan kültürü insidansin1 \%97'den \%91 e düşürdüğü bildirilmiștir (10). Tunkel ve ark. (11) tarafindan yapilan bir çalışmada antibiyotik kullanım süresinin de önemli bir faktör olduğu, sadece 2-3 gün antibiyotik kullanım hikayesi varsa başlangıçta negatif olan kan kültürünün hızlıca pozitifleştiği, fakat daha uzun süreli küratif olmayan tedavi sonrasinda haftalarca kan kültürlerinin negatif kaldığ1 gösterilmiştir (11). Kan kültürlerinde üreme olmayan bu hastada da başvuru öncesi bir hafta süresince antibiyotik kullanım hikayesi mevcuttu. Yapılan bir çalışmada negatif venöz kan kültürü olan vakaların hiçbirinde pozitif arteriyel kan kültürü saptanmamış olup, arteryel ve venöz kan kültürü negatif olan beş vakanın ise kemik iliği kültür sonucu pozitif olarak bildirilmiştir. Sonuç olarak arteryel kan kültürünün EE tanisı konulmasinda faydalı olmadığı, devamlı venöz kan kültürü negatifliği olan nadir vakalarda kemik iliği kültürünün tanisal bilgi verebileceği sonucuna varılmıştır (12). Bizim hastamızda da kan kültürü negatif olmasına rağmen kemik iliği kültür sonucu ile tanı konulmuştur.

EE şüphesi olan hastalarda birinci basamak TTE yapilmasi önerilmektedir. Normal TTE bulguları olan hastalarda EE şüphesi devam etmekte ise TEE yapilması, başlangıç ekokardiyografileri negatif olan ve klinik şüphesi devam eden hastalarda ise T'TE/TEE'nin 7-10 gün içinde tekrarlaması önerilmektedir. (5). Yapılan çalışmalarda TTE sensitivitesi \%40-63 arasında değişirken, TEE'nin ise \%90-100 dür. Bizim vakamızda ilk yapilan TTE normal olup tekralanan TTE sonucunda vejetasyon saptanmıştır. T'TE'nin erken kullanımı EE tanısının hizlı konulmasını sağlar. Fakat yapılan çalışmalarda pozitif prediktivitesi sadece \%57 olarak bulunmuştur. TTE; EE tanısında tek başına ideal bir method olmayıp güvenli, basit ve ucuz bir yöntem olması ile en uygun ilk basamak görüntüleme yöntemi kabul edilmektedir (3).

\section{SONUÇ}

Enfektif endokarditin tan1 ve tedavi prosedürlerinde önemli gelişmeler olmasina rağmen hala bu hastalık kötü prognoza ve yüksek mortaliteye sahiptir. $\mathrm{Bu}$ nedenle hizlı tanı konmasi ve erken tedaviye başlanmasının prognoza önemli etkisi bulunmaktadir (5). Fakat EE vakalarının da farklı prezentasyonları tanıyı güçleştirmektedir (3). Ateşsiz seyreden, kan kültürleri negatif olan ve ilk TTE'de vejetasyon görülmeyen bu vakada olduğu gibi ateş odağ araştırılırken enfektif endokardit farklı klinik prezentasyonları nedeni ile etiyolojide yine de akilda bulundurulmalidır. EE tanısında kemik iliği kültürünün de tanısal bilgi verebileceği unutulmamalıdır.. 


\section{KAYNAKLAR}

1. Douglas CWI, Heath J, Hampton KK, Preston FE. Identity of viridans streptococci isolated from cases of infective endocarditis. J Med Microbiol 1993;39:179-182

2. Doern CD, Burnham CD. It's not easy being green: The viridans group streptococci, with a focus on pediatric clinical manifestations. J Clin Microbiol 2010;3829-3835

3. Todd AJ, Leslie SJ, Macdougall M, Denvir MA. Clinical features remain important for the diagnosis of infective endocarditis in the modern era. Q J Med 2006;99:23-31

4. Akova M, Şardan YÇ. Enfektif endokardit, miyokardit, perikardit. Enfeksiyon Hastalıkları ve Mikrobiyolojisi Editörler: Ayşe W. Topçu, Güner Söyletir, Mehmet Doğanay. 3. Bask1. Türkiye 2008.
5. Habib G, Hoen B, Tornos P,Thuny F, Prendergast B, Vilacosta I et all. Guidelines on the prevention, diagnosis and treatment of infective endocarditis of European Society od Cardiology (ESC). Eur Heart J 2009;30:2369-2413

6. Mylonakis E, Calderwood SB. Infective endocarditis in adults. $\mathrm{N}$ Engl J Med $2001 ; 345,18$

7. Hoen B, Duval X. Infective endocarditis. N Engl J Med 2013;368,15

8. Elbey MA, Kalkan ME, Kaya MG, Sayın MR, Karapinar H, Bulur, Ulus T et all. A multicenter study on experience of 13 tertiary hospitals in Turkey in patients with infective endocarditis. Anadolu Kardiyol Derg 2013;13:523-527

9. Brouqui P, Raoult D. Endocarditis due to rare and fastidious bacteria. Clin Microbiol Rev 2001;14:177-207.
10. Werner AS, Cobbs CG, Kaye D, Hook EW. Studies on the bacteremia of bacterial endocarditis. JAMA 1967; 202:199-203

11. Tunkel AR, Kaye D. Endocarditis with negative blood culture. N Engl J Med 1992;326:1215-1217

12. Salazar MM, Lozane HE, Brenes M. Comparative study of blood cultures made from artery, vein, and bone marrow in patients with subacute bacterial endocarditis. Am Heart J 1947;33:692695. 